\title{
Materials to the fauna of aquatic bugs of the infraorder Nepomorpha (Heteroptera) of the Javakheti Highland, Georgia
}

\author{
Материалы к фауне водных полужкесткокрылых инфраотряда \\ Nepomorpha (Heteroptera) Алжавахетского нагорья, Грузия
}

\author{
Maksim I. Shapovalov ${ }^{1}$, Maksim A. Saprykin ${ }^{1}$, Bella Japoshvili², \\ Levan Mumladze ${ }^{2}$ \\ М.И. Шаповалов ${ }^{1}$, М.А. Сапрыкин ${ }^{1}$, Б. Ажкапошвили ${ }^{2}, \Lambda$. Мумладзе $^{2}$ \\ ${ }^{1}$ Laboratory for Bioecological Monitoring of the Invertebrates of the Republic of Adygeya, Adyghe State University, Pervomayskaya 208, \\ Maikop 385000, Adygea Republic, Russia. E-mail: shapmaksim2017@yandex.ru \\ ${ }^{2}$ Biodiversity Research Center, Institute of Ecology and Institute of Zoology, Ilia State University, Cholokashvili Ave. 3/5, Tbilisi 0162, \\ Georgia. E-mail: 1mumladze@gmail.com \\ 1 Лаборатория биоэкологического мониторинга беспозвоночных животных Адыгеи, Адыгейский государственный университет, \\ Первомайская 208, Майкоп 385000, Республики Адыгея, Россия. \\ 2 Центр исследования биоразнообразия, Институт экологии и зоологии, Государственный университет Ильи, проспект Чолокашвили, \\ 3/5, Тбилиси, 0162, Грузия.
}

KEY WORDS: Heteroptera, Nepomorpha, Cymatia bonsdorffii, new records, fauna, Javakheti Highland, Georgia.

КЛЮЧЕВЫЕ СЛОВА: Heteroptera, Nepomorpha, Cymatia bonsdorffii, новые находки, фауна, Джавахетское нагорье, Грузия.

ABSTRACT. An annotated checklist of aquatic bugs of 12 species of nine genera and four families of the infraorder Nepomorpha from montane lakes of Javakheti higland (Georgia), is provided. Cymatia bonsdorffii (C.R. Sahlberg, 1819) is recorded for the first time for the fauna of Georgia.

РЕЗЮМЕ. В работе впервые приводятся сведения о 12 видах водных клопов подотряда Nepomorpha из 9 родов и 4 семейств, населяющих горные озёра Джавахетского нагорья, Грузия. Cymatia bonsdorffii (C.R. Sahlberg, 1819) впервые указывается для фауны Грузии.

\section{Introduction}

Javakheti Highland is a volcanic highland in southern Georgia, consisting of meridional ranges (Abul-Samsari and Javakheti) up to $3300 \mathrm{~m}$ a.s.l. and plateaus (Tsalka, Gomarethi and Akhalkalaki) with altitudes from 1200 to $2200 \mathrm{~m}$ a.s.l. [Adamia et al., 2011]. Highland is composed of andesite-basalt and trachytic lavas and most of its landscapes are represented by montane steppes and subalpine meadows. The Javakheti Highland is very rich in lentic waterbodies, including more than 60 lakes and many bogs of different succession stages. The lakes are either volcanic or glacial origin [Apkhazava, 1975]. The Javakheti Highland is strongly continental, with average annual precipitation in Akhalkalaki (the geographical and political center of the region) not exceeding $550 \mathrm{~mm}$ (a maximum of $100 \mathrm{~mm}$ in June and $25 \mathrm{~mm}$ on average in January, the driest month). Winter is long and cold, summer is short and cool. The average temperature of January is $-7^{\circ} \mathrm{C}$, while the average of July is 12 to $13^{\circ} \mathrm{C}$ [Messager et al., 2013].

Studies on the fauna of waterbodies of the Javakheti Highland are scarce. There are several studies describing the biodiversity and ecological pecularities of the macrozoobenthos communities of several large lakes of the Javakheti Highland [Sadovski, 1933; Ovinnikova, 1959; Tskhomelidze et al., 1961; Pataridze, 1962, 2002; Pataridze, Gioshvili, 2015; Gabelashvili et al., 2016; Shubitidze et al., 2018].

In this paper, provide data on the fauna of aquatic bugs of the infraorder Nepomorpha from montane lakes of Javakheti Higland.

\section{Material and methods}

The field work in the Javakheti Highland was carried out in the period of 2015-2017. The investigated montane lakes are located between altitudes from 1580

How to cite this article: Shapovalov M.I., Saprykin M.A., Japoshvili B., Mumladze L. 2019. Materials to the fauna of aquatic bugs of the infraorder Nepomorpha (Heteroptera) of the Javakheti Highland, Georgia // Russian Entomol. J. Vol.28. No.2. P.120 -124. doi: 10.15298/rusentj.28.2.02 
to $2870 \mathrm{~m}$ a.s.l. (Fig. 1). The collection of aquatic bugs is deposited in the Institute of Zoology of Ilia State University (Tbilis, Gergia) and the Laboratory of Bioecological Monitoring of Invertebrate Animals of Adyghea, Research Institute of Complex Problems, Adyghe State University (Maykop, Russia).

The material was collected using kick-net in lake littoral areas, followed immediate fixation of samples in $96 \%$ ethanol and labeling. Identification was performed in the laboratory using a Micromed MC-3 ZOOM Led stereo microscope. Dissection of the genitalia and mounting of the specimens was performed using the standard technique [Kerkis, 1926; Golub et al., 2012]. Coordinates of localities were determined in the field using GPS.

The annotated checklist for each species includes localities of the Javakheti Highland, the number of collected specimens and sex, with additional remarks.

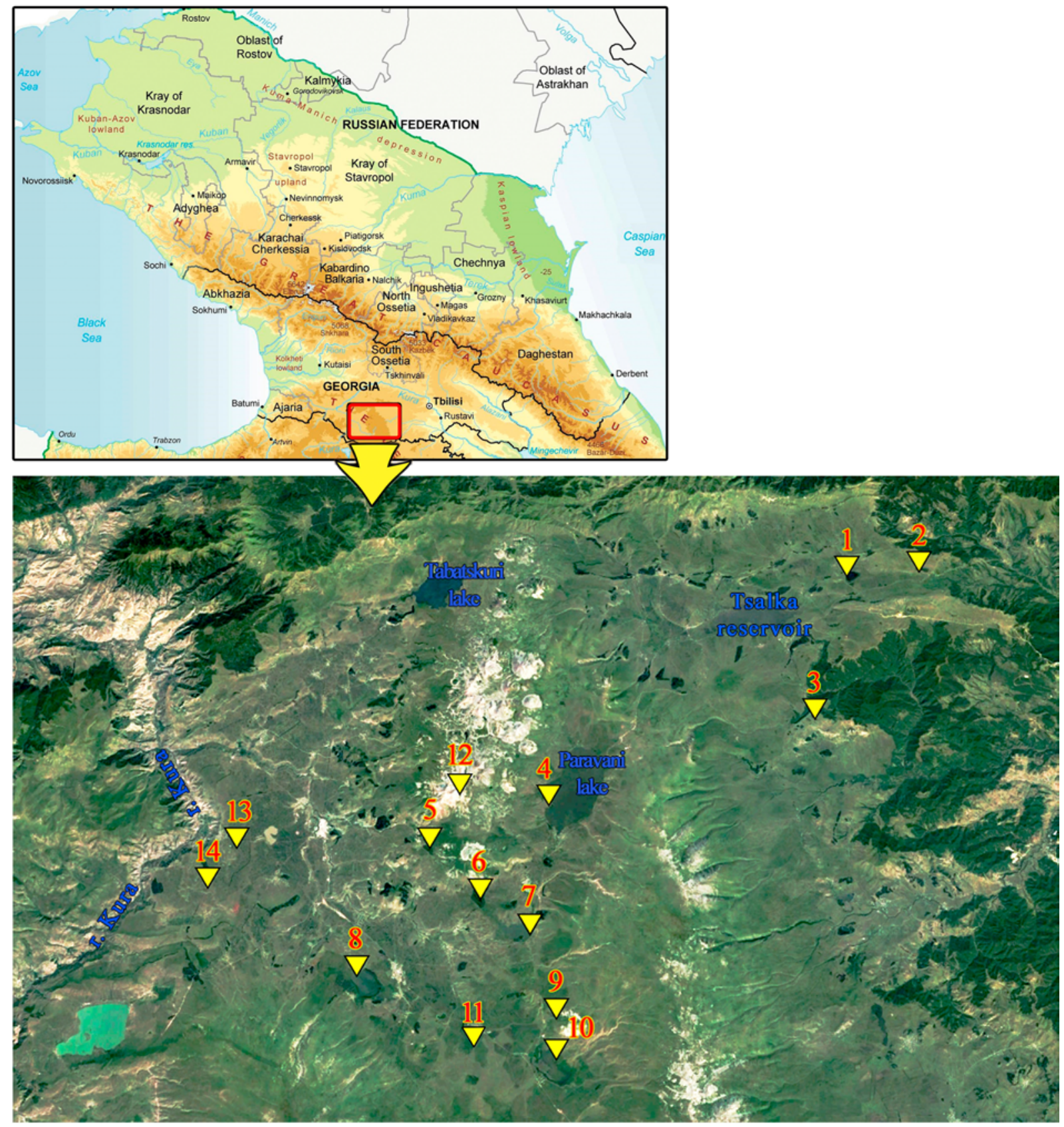

Fig. 1. Collecting sites of aquatic bugs in the Javakheti Highland, Georgia: 1 - Bareti Lake; 2 - Tba Lake; 3 - Chamligoli Lake; 4 - Paravani Lake; 5 - Abulis Lake; 6 - Avchala Lake; 7 - Saghamo Lake; 8 - Khanchali Lake; 9 - Bikentnoe Lake; 10 - Madatapa Lake; 11 - Bughdasheni Lake; 12 - Khukhuruzi Lake; 13 - Ucnobi Lake; 14 - Didi Tba Lake.

Рис. 1. Пункты сбора водных клопов на территории Джавахетского нагорья, Грузия: 1 - озеро Барети; 2 - озеро Тба; 3 - озеро Чамлиголи; 4 - озеро Паравани; 5 - озеро Абули; 6 - озеро Авчала; 7 - озеро Сагамо; 8 - озеро Ханчали; 9 - озеро Бикетное; 10 - озеро Мадатапа; 11 - озеро Бугдашени; 12 - озеро Чухурузи; 13 - озеро Уцноби; 14 - озеро Диди Тба. 


\section{Results}

Annotated checklist of aquatic bugs of the infraorder Nepomorpha, from the Javakheti Highland

\section{Infraorder NEPOMORPHA Popov, 1968 Family Corixoidea Leach, 1815}

Cymatia bonsdorffii (C.R. Sahlberg, 1819) Figs 2-6.

MATERIAL. Ninotsminda Municipality: near the Zhdanovka village, Madatapa lake ( $\left.41^{\circ} 11^{\prime} 22.5^{\prime \prime} \mathrm{N} 43^{\circ} 47^{\prime} 40.5^{\prime \prime E}\right), 2110 \mathrm{~m}$ a.s.1.

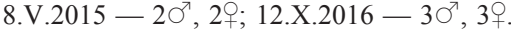

REMARKS. The species was reported from Azerbaijan (Karabakh) [Kirichenko, 1918], but in later studies this species has not been mentioned in the Caucasus. The species is present in Europe (except in the south), European part of Russia, Siberia, East Kazakhstan, Mongolia, Northeast China, the Far East [Jansson, 1995; Kanyukova, 2006]. An earlier record of the species in Turkey [Nieser, Moubayed, 1985], was proven wrong [Fent et al., 2011]. The species is recorded for the first time in Georgia.

\section{Cymatia coleoptrata (Fabricius, 1777)}

MATERIAL. Dmanisi Municipality: $1.3 \mathrm{~km}$ N Sarkineti village, Chamligoli Lake (41 $\left.30^{\circ} 34.6^{\prime \prime} \mathrm{N} 44^{\circ} 07^{\prime} 14.5^{\prime \prime} \mathrm{E}\right), 1580 \mathrm{~m}$ a.s.1. 15.V.2017 - $2 \sigma^{\circ}, 3$ 요.

REMARKS. The species has been recorded in Georgia in the Turtle (Cherepashye) lakes near Tiflis (Tbilisi) [Kirichenko, 1930].

\section{Monticorixa armeniaca (Štys, 1975)}

MATERIAL. Akhalkalaki Municipality: Khkhuruzi Lake,

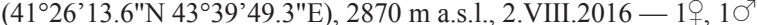

REMARKS. In the Caucasus, the species has been recorded in Armenia [Jansson, 1995] and Georgia [Kanyukova, 2006].

\section{Callicorixa raddei (Kirichenko et Jaczewski, 1960)} Figs 7-12.

MATERIAL. Ninotsminda Municipality: $3 \mathrm{~km}$ N Poka village, Paravani Lake $\left(41^{\circ} 25^{\prime} 344^{\prime \prime N} 43^{\circ} 46^{\prime} 49.0^{\prime \prime} \mathrm{E}\right), 2080 \mathrm{~m}$ a.s.1.

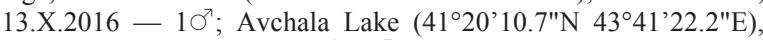
2055 m a.s.1., 12.V.2016-3ㅇ, $20^{7}$; Biketnoye Lake, (41 ${ }^{\circ} 13^{\prime} 11.6^{\prime \prime} \mathrm{N}$ 4346'33.2"E) $2175 \mathrm{~m}$ a.s.1., 11.V.2016 - 1, $10^{7}$; Khanchali Lake (41 $\left.{ }^{\circ} 15^{\prime} 47.7^{\prime \prime} \mathrm{N} 43^{\circ} 32^{\prime} 09.3^{\prime \prime E}\right), 1928 \mathrm{~m}$ a.s.1., 2.VIII.2015 - 9웅 $30^{7}$; near the Saghamo village, Saghamo Lake $\left(41^{\circ} 18^{\prime} 05.7^{\prime \prime} \mathrm{N}\right.$ $\left.43^{\circ} 45^{\prime} 23.9^{\prime \prime E}\right), 1984 \mathrm{~m}$ a.s.1., 31.X.2015 - $10^{7}$; near the Zhdanov-

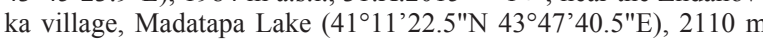
a.s.1., 8.V.2015 - 3o; upper reaches of the Zagranichnaia river, Bughdasheni Lake (41 $\left.11^{\prime} 56.9^{\prime \prime} \mathrm{N} 43^{\circ} 41^{\prime} 14.0^{\prime \prime E}\right), 2040 \mathrm{~m}$ a.s.1., 5.VIII.2015 - 3; 4.VIII.2015 2ᄋ, $2 \sigma^{7}$; 2.XI.2015-2+, $2 \sigma^{\prime}$; Akhalkalaki Municipality: Ucnobi Lake (41 23 '10.19"N $43^{\circ} 22^{\prime} 48.40^{\prime \prime E)}, 1760 \mathrm{~m}$ a.s.1., 16.V.2016 - 3ㅇ, $20^{\top}$.

REMARKS. Kirichenko [1918] recorded Callicorixa praeusta (Fieb.) in Georgia (Bakuriani, Tabatskuri). Later, Kirichenko and Jaczewski [1960] described the species Callicorixa raddei (as Sigara (Callicorixa) raddei) based on materials from Georgia (Bakuriani), Armenia (lakes of Sevan, Jil, Yerevan, Leninakan) and Turkey. According to Kanyukova [2006], all records of C. praeusta in Georgia and Armenia should be considered as $C$. raddei. Our findings also confirm the later suggestion.

\section{Corixa dentipes Thomson, 1869}

MATERIAL. Ninotsminda Municipality: Abuli Lake (41 $\left.23^{\prime} 06.5^{\prime \prime} \mathrm{N} 43^{\circ} 37^{\prime} 26.0^{\prime \prime E}\right), 2185 \mathrm{~m}$ a.s.1., 18.V.2016 - $10^{7}$;

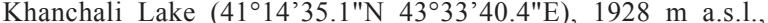
2.VIII.2015 - $20^{7}$; near the Zhdanovka village, Madatapa Lake $\left(41^{\circ} 11^{\prime} 22.5^{\prime \prime} \mathrm{N} 43^{\circ} 47^{\prime} 40.5 " \mathrm{E}\right), 2110 \mathrm{~m}$ a.s.1., 11.V.2016-10'. REMARKS. In Georgia, the species was recorded in Tba Lake and Gveleti village [Kirichenko, 1930].

\section{Hesperocorixa linnaei (Fieber, 1848)}

MATERIAL. Ninotsminda Municipality: Tba Lake,

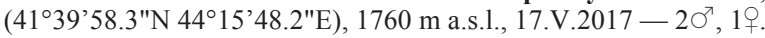
REMARKS. In Georgia, the species was recorded in Tiflis (Tbilisi) [Kirichenko, 1918].

Sigara (Retrocorixa) limitata limitata (Fieber, 1848)

MATERIAL. Ninotsminda Municipality: Avchala Lake

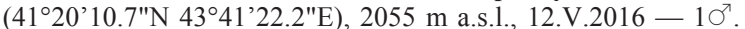

REMARKS. In Georgia, the species was recorded in Tiflis (Tbilisi) [Kirichenko, 1918].

Sigara (Sigara) striata (Linnaeus, 1758)

MATERIAL. Tsalka Municipality: Bareti Lake (41³9’35.6"N

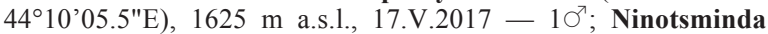
Municipality: $3 \mathrm{~km} \mathrm{~N}$ Poka village, Paravani Lake $\left(41^{\circ} 25^{\prime} 34.4^{\prime \prime} \mathrm{N}\right.$

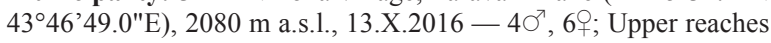
of the Zagranichnaia river, Bughdasheni Lake $\left(41^{\circ} 11^{\prime} 56.9^{\prime \prime} \mathrm{N}\right.$ $\left.43^{\circ} 41^{\prime} 14.0^{\prime \prime E}\right), 2040 \mathrm{~m}$ a.s.1., 2.XI.2015 - 3ㅇ, 40'.

REMARKS. Georgia [Kanyukova, 2006].

\section{Family Naucoridae Leach, 1815}

Ilyocoris cimicoides cimicoides (Linnaeus, 1758)

MATERIAL. Tsalka Municipality: Bareti Lake (41³9’35.6"N

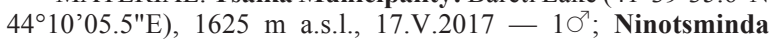

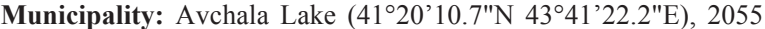
$\mathrm{m}$ a.s.1., 1.VIII.2016 - 12 lav.; Akhalkalaki Municipality: (412 $\left.21^{\prime} 12.2^{\prime \prime} \mathrm{N} 43^{\circ} 20^{\prime} 28.3^{\prime \prime E}\right)$, Didi Tba Lake, $1780 \mathrm{~m}$ a.s.1., 31.VII.2016 - 6 larv.

REMARKS. In Georgia, the species was recorded in Tiflis (Tbilisi) and Bacuriani [Kirichenko, 1918].

\section{Family Notonectidae Latreille, 1802}

Notonecta (Notonecta) reuteri Hungerford, 1928

MATERIAL. Ninotsminda Municipality: $3 \mathrm{~km}$ N Poka village, Paravani Lake $\left(41^{\circ} 25^{\prime} 34.4^{\prime \prime} \mathrm{N} 43^{\circ} 46^{\prime} 49.0^{\prime \prime} \mathrm{E}\right), 2080 \mathrm{~m}$ a.s.1.,

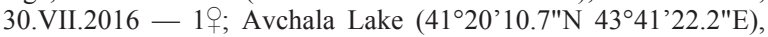
$2055 \mathrm{~m}$ a.s.1., 1.VIII.2016 - $1 \mathrm{O}^{7}$; near the Zhdanovka village, Madatapa Lake $\left(41^{\circ} 11^{\prime} 22.5^{\prime \prime} \mathrm{N} 43^{\circ} 47^{\prime} 40.5^{\prime \prime E}\right), 2110 \mathrm{~m}$ a.s.1., 1.VIII. $2015-10^{7}, 1$ ㅇ․

REMARKS. Records of Notonecta lutea Müller, 1776 from Georgia (Tabatskuri lake) by Kirichenko [1918], belong to Notonecta reuteri [Kanyukova, 2006].

Notonecta (Notonecta) viridis Delcourt, 1909

MATERIAL. Akhalkalaki Municipality: $\left(41^{\circ} 21^{\prime} 12.2^{\prime \prime} \mathrm{N}\right.$ $43^{\circ} 20^{\prime} 28.3^{\prime \prime E)}$, Didi Tba Lake, $1780 \mathrm{~m}$ a.s.1., 31.VII.2016 - $2{ }^{\circ}$.

REMARKS. In Georgia, this species was recorded as Notonecta marmorea, in Tiflis (Tbilisi), Bakuriani, Borjomi, Lagodekhi, Shakriani, Dedoplistskaro [Kirichenko, $1930]$.

\section{Family Pleidae Fieber, 1851}

Plea minutisima minutisima Leach, 1817

MATERIAL. Dmanisi Municipality: $1.3 \mathrm{~km}$ N Sarkineti village, Chamligoli Lake (41 $\left.30^{\circ} 34.6^{\prime \prime N} 44^{\circ} 07^{\prime} 14.5^{\prime \prime E}\right), 1580 \mathrm{~m}$ a.s.1., 15.V.2017 - 20'; Akhalkalaki Municipality: $\left(41^{\circ} 21^{\prime} 12.2^{\prime \prime} \mathrm{N}\right.$ $\left.43^{\circ} 20^{\prime 2} 28.3^{\prime \prime E}\right)$, Didi Tba Lake, $1780 \mathrm{~m}$ a.s.1., 31.VII.2016 - 12 specimens.

REMARKS. In Georgia, this species was recorded in Tiflis (Tbilisi) [Kirichenko, 1918]; and later as Plea atomaria (Pallas, 1771) also in Tiflis (Tbilisi) [Kirichenko, 1930]. 

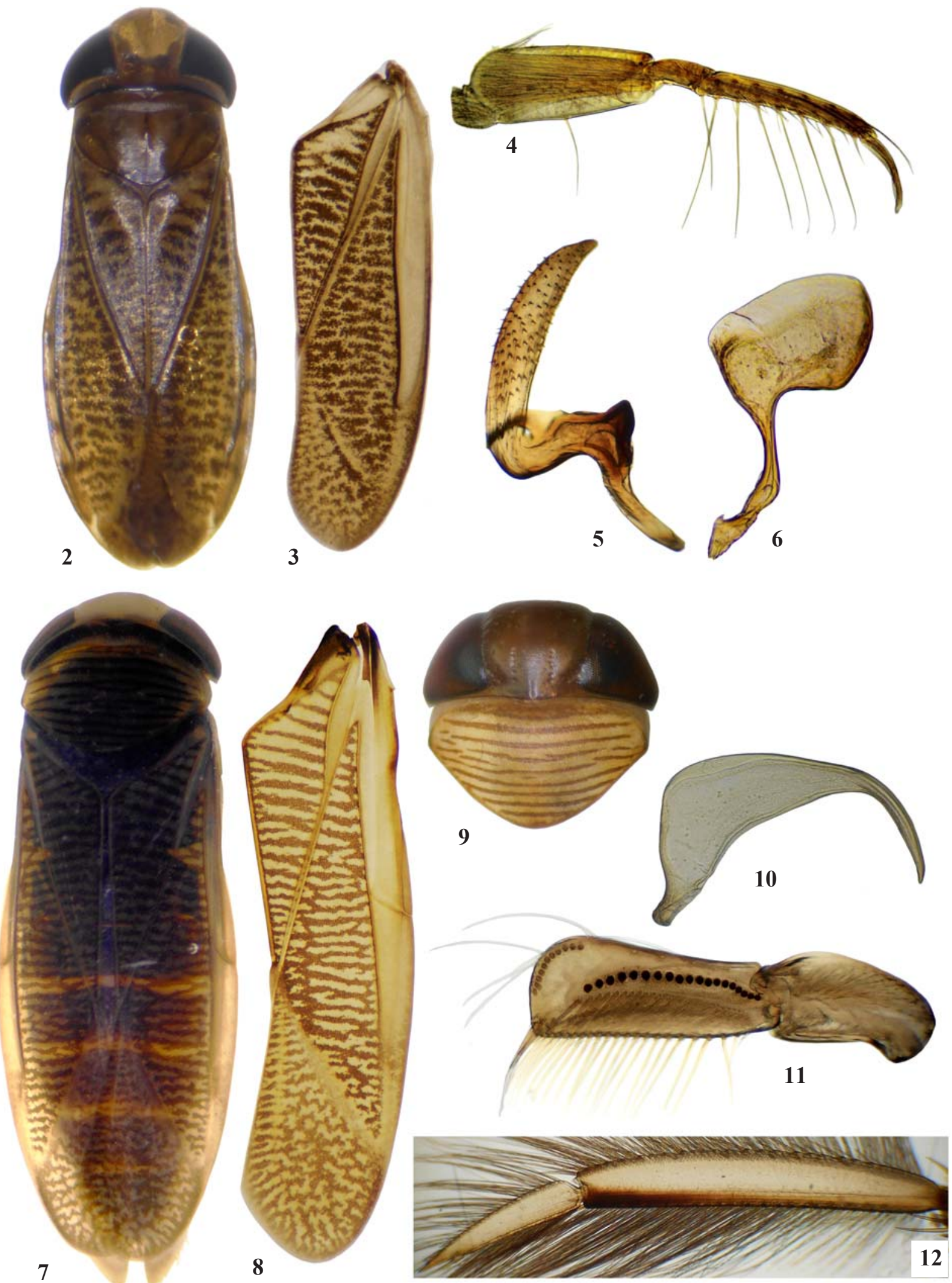

Figs 2-12. 2-6-Cymatia bonsdorffii; 7-12-Callicorixa raddei; 2, 7 - imago habitus; 3, 8 - hemelytron; 4, 11 - $0^{7}$ pala (ventral view); 5 - left paramere; 6,10 - right paramere; 9 - head and pronotum; 12 - metatarsus.

Рис. 2-12. 2-6 - Cymatia bonsdorffii; 7-12 - Callicorixa raddei; 2, 7 - имаго; 3, 8- надкрылье; 4, 11 - передняя лапка $0^{7}$ (снизу); 5 - парамер левый; 6, 10 - парамер правый; 9 - голова и переднеспинка; 12 - задняя лапка. 
In total 12 species of aquatic bugs were found in the lakes of Javakheti Highland. Apparently, further research should also provide additional data for this area since the most of the lotic and lentic systems are yet to be studied. Since the Javakheti Highland is an important conservation target [Matcharashvili et al., 2004], we hope that the knowledge of the regional invertebrate biodiversity will trigger further research in the region as well as help in conservation prioritization and establishing biological monitoring programs.

Acknowlegdments. The study of B. Japoshvili and L. Mumladze was supported by the Shota Rustaveli National Scientific Foundation (Research Grant: FR/479/7-130/13).

\section{References}

Adamia S., Zakariadze G., Chkhotua T., Sadradze N., Tsereteli N., Chabukiani A., Gventsadze A. 2011. Geology of the Caucasus: a review // Turkish Journal of Earth Sciences. Vol.20. No.5. P.489-544.

Apkhazava I. 1975. [Lakes of Georgia]. Tbilisi: Metsniereba. 181 p. [In Russian]

Fent M., Kment P., Çamur-Elipek B., Kirgiz T. 2011. Annotated catalogue of Enicocephalomorpha, Dipsocoromorpha, Nepomorpha, Gerromorpha, and Leptopodomorpha (Hemiptera: Heteroptera) of Turkey, with new records // Zootaxa. Vol.2856. P.1-84.

Gabelashvili S., Bikashvili A., Shubitidze Z., Gioshvili M., Pankvelashvili E., Mumladze L., Japoshvili B. 2016. Family level diversity and distribution of macroinvertebrates of Madatapa, Khanchali and Bughdasheni lakes in Javakheti plateau (South Georgia) // Proceedings of the Institute of Zoology. Tbilisi. Vol.25. P.117-128.

Golub V.B., Tsurikov M.N., Prokin A.A. 2012. [Insect collections: collecting, processing and storage of materials]. Moscow: KMK Scientific Press. 339 p. [In Russian]

Jansson A. 1995. Family Corixidae Leach, 1815 water boatmen // B. Aukema, Chr. Rieger (Eds). Catalogue of the Heteroptera of the Palaearctic Region. I. Amsterdam: Netherlands Entomological Society. P.26-56.

Kanyukova E.V. 2006. [Aquatic and semiquatic bugs (Heteroptera: Nepomorpha, Gerromorpha) of the fauna of Russia and neighbouring countries]. Vladivostok: Dalnauka. 279 p. [In Russian with English title]
Kerkis Y.K. 1926. [To the knowledge of internal genitalia of aquatic Hemiptera-Hetroptera]//Entomologicheskoe Obozrenie. Vol.20. No.4. P.234-307 [in Russian, with English summary].

Kiritshenko A.N. 1918. [Hemiptera-Heteroptera of the Caucasus region. Pars I] // Zapiski Kavkazskogo Muzeya. Seriya A. No.6. P.1-177 [in Russian, with Latin title].

Kiritshenko A.N. 1930. [Die in Nordwestpersien und im Kaukasus von D.A. Tarnogradsky gesammelten Hemiptera Heteroptera aquatica (Hydrobiotica et Sandaliorhyncha)] // Travaux de la station bioloogique du caucase du Nord. No.3. P.45-62 [in Russian].

Kirichenko A.N., Jaczewski T.L. 1960. [New species of the genus Sigara (Hemiptera, Corixidae) of Transcaucasia] // Entomologicheskoe obozrenie. Vol.39. No.1. P.182-186 [in Russian].

Matcharashvili I., Arabuli G., Darchiashvili G., Gorgadze G. 2004. [Wetland ecosystems of Javakheti: biodiversity and conservation]. Tbilisi: CGS Kalamus Graphic Ltd. 62 p. [In Georgian]

Messager E., Belmecheri S., von Grafenstein U., Nomade S., Ollivier V., Voinchet P., Puaud S., Courtin-Nomade A., Guillou H., Mgeladze A., Dumoulin J.P, Mazuy A., Lordkipanidze D. 2013. Late Quaternary record of the vegetation and catchment-related changes from Lake Paravani (Javakheti, South Caucasus) // Quaternary Science Reviews. Vol.77. P.125-140.

Nieser N., Moubayed Z. 1985. Les Hétéroptères aquatiques du Liban. I. Inventaire faunistique// Annales de Limnologie. Vol.21. P.247-252.

Ovinnikova V.V. 1959. [Feeding base of Paravani Lake, Saghamo Lake and Tsalka Reservoir benthic feeding fish in 1958] // Proceedings of Scientific-Research Station of Georgia. Vol.4. P.24-29 [in Russian].

Pataridze A.I. 1962. [Materials on Oligochaetas of Paravani Lake] // Soobshcheniya Akademii nauk Gruzinskoi SSR. Vol.29. P.203207 [in Russian]

Pataridze A.I. 2002. Zoobenthos of Paravani Lake // Proceedings of the Institute of Zoology. Vol.21. P.379-386.

Pataridze A., Gioshvili M. 2015. Zoobenthos of Saghamo Lake // Proceedings of the Institute of Zoology. Vol.24. P.171-176.

Sadovski A.A. 1933. [Hydrobiology of Paravani and Tabatskuri Lakes, "Javakheti"] // Materials on the study of natural resources of the Akhalkalak plateau. P.219-226 [in Russian].

Shubitidze Z., Japoshvili B., Pataridze A., Bikashvili A., Gabelashvili S., Mumladze L. 2018. Diversity of Oligochaeta worms (Annelida) in Madatapa lake (South Georgia) // Proceedings of the Institute of Zoology. Vol.26. P.125-127.

Tskhomelidze O.I., Sergeeva Zh., Ovinnikova V. 1961. [Feeding resource in high mountain lakes Madatapa, Khanchali and Bareti] // Trudy Nauchno-isledovatel'skooy Rybokhozyaystvennoy Stantsii Gruzii. Vol.6. P.38-48 [in Russian]. 